\title{
РЕНТГЕНОЛОГІЧНА ХАРАКТЕРИСТИКА ЕФЕКТИВНОСТІ ЛІКУВАННЯ КОТІВ, ХВОРИХ НА ГНІЙНИЙ ОСТЕОМІЄЛІТ
}

\section{Рецензент - кандидат ветеринарних наук, доцент Р. В. Передера}

\begin{abstract}
Наведено дані рентгенологічних досліджень після застосування транульованих імплантантів БіомінгТлС для пластики кісткових дефектів. Встановлено, щуо застосування ичих імплантантів призводить до активізації прочесів репаративного остеогенезу та відтворення анатомічної форми й структури кістки. Ренттенологічно виявлені та описані основні зміни тканин, характерні для остеомієліту. Доведено, щзо ренттенологічне дослідження дає можливість діагностувати остеомієліт на ранній стадї та призначити ефективне лікування.
\end{abstract}

Ключові слова: остеомієліт, ренттенографія, остеопластика, коти.

Постановка проблеми. Лікування остеомієліту у котів залишається актуальною проблемою ветеринарної хірургії. На нашу думку, це пов'язано з переважно хронічним чи латентним перебігом патології, а також складністю іiі діагностики та лікування.

Аналіз останніх досліджень i публікацій, у яких започатковано розв'язання проблеми. Загальноприйнятою $є$ комплексна терапія хворих на остеомієліт, що передбачає хірургічну радикальну санацію гнійно-некротичного вогнища 3 проведенням реконструктивно-відновних операцій на фоні антибактеріальної терапії 3 корекцією основних показників гомеостазу та імунного статусу організму.

Сучасний етап розвитку реконструктивної ветеринарної хірургії характеризується інтенсивними пошуками нових засобів. Останнім часом чимало уваги надається матеріалам, які, виконуючи функцію тимчасового направляючого каркаса для регенерації, заміщуються поступово власними тканинами організму.

Доцільним для пластики кісткових дефектів $\epsilon$ використання неорганічної складової кісткової тканини - гідроксилапатиту. Його перевага перед іншими імплантантами полягає у високій біосумісності та здатності розсмоктуватися (з різною швидкістю, залежно від розмірів кристалів і особливостей синтезу). У літературі описано чимало різних імплантантів на основі гідроксилапатиту, що позитивно впливають на репаративну регенерацію кістки [1, 2, 4-6].

Мета досліджень - рентгенологічна оцінка репаративних процесів у кістковій тканині в разі застосування гранульованого імплантанту Біомін-гТлС за комплексного лікування гнійного остеомієліту котів.

Завдання: рентгенологічно виявити та описати основні зміни тканин, характерні для остеомієліту.

Матеріали і методи досліджень. У 21-го кота моделювали експериментальний гнійний остеомієліт кісток плеча, передпліччя та нижньої щелепи.

Тваринам проводили некросеквестректомію і пластику кісткової порожнини. Для цього використовували гранульований імплантант БіомінгТлС (гідроксилапатит + $\beta$-трикальційфосфат, леговані сріблом). Біомін (Центр науковотехнічних послуг «Рапід», Україна) - керамічний гідроксилапатит (ГАП) - хімічний аналог мінеральної речовини кістки ссавців. Біомін внесений до Державного реєстру медичних виробів, дозволених до використання в Україні, за № 9438/2010 (наказ МО3 України від 25.06.2010 p. № 314). Для стимуляції репаративних процесів, антиоксидантного захисту організму в післяопераційний період тваринам застосовували препарат «Румосол». Препарат призначали відповідно 3 настановою до його використання. Крім того у післяопераційному періоді тваринам обох груп проводили курс антибіотикотерапії (комбікел та лінкоміцин).

Рентгенологічні дослідження проводили в боковій і прямій проекціях на діагностичному переносному апараті «Арман» 9Л5 У2* з використанням медичної радіографічної плівки Кровалекс-ОРГ синьочутливої $13 \times 18$ при жорсткості

* Науковий керівник - доктор ветеринарних наук Б. П. Киричко 
60 кВ та експозиції $2,5 \mathrm{~mA} / \mathrm{c}$, а дослідження нижньої щелепи - за допомогою внутрішньоротової плівки $2 \times 3$ см при жорсткості 50 кВ та експозиції $4 \mathrm{~mA} / \mathrm{c}$. Для оцінки рентгенологічних знімків користувалися рентгенологічним атласом із травматології собак та кішок $[3,7]$.

Під час виконання експериментальних досліджень дотримувалися міжнародних вимог « $\mathrm{C}_{\mathrm{B}}$ ропейської конвенції захисту хребетних тварин, що використовуються в експериментальних та інших наукових цілях» (Страсбург; Франція, 1986 р.) та відповідного Закону України «Про захист тварин від жорстокого поводження» № 3447-IV від 21.02.2006 року.

Результати досліджень. На початку експерименту у тварин рентгенологічно виявляли дефект у середній третині променевої та ліктьової кісток. У окремих тварин визначалися секвестри 3 нечіткими контурами, поширення кісткової деструкції вбік від післяопераційних отворів (рис. 1,2$)$ та патологічні переломи в ділянці деструкції (рис. 3 ).

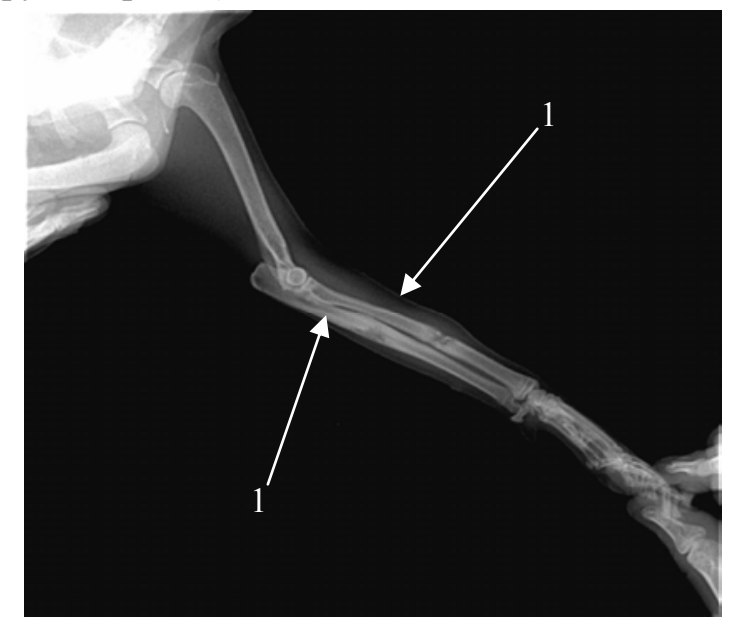

Рис. 1. Рентгенограма кісток передпліччя у кота за остеомієліту: 1 - секвестральні коробки

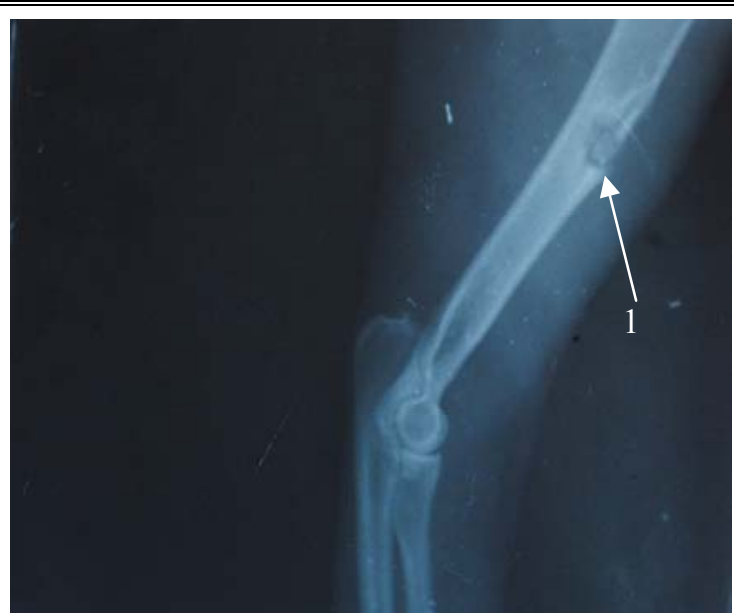

Рис. 2. Ренттенограма плечової кістки кота. Утворення секвестральної коробки:

$$
1 \text { - секвестральна коробка }
$$

Для лікування гнійного остеомієліту ми проводили доопераційну підготовку шляхом комбінованого анестезіологічного забезпечення та фіксації у лежачому положенні (спинному чи боковому) в залежності від локалізації патологічного процесу. Уражену ділянку готували до оперативного втручання 3 дотриманням вимог асептики й антисептики. Після цього виконували оголення кітки повздовжнім розрізом м'яких тканин і окістя, відшарування стовщеного окістя й розкривання секвестральної коробки по ходу нориці. Кюректаж некротизованих ділянок виконували за допомогою портативного апарату БУС-02 з набором кісткових фрез.

Після цього кісткову порожнину висушували шляхом тугої тампонади стерильними марлевими тампонами, зрошували антисептичним засобом та заповнювали гранульованими імплантантами 3 гідроксилапатиту керамічного БіомінгТлС. Далі проводили ревізію м'яких тканин і рану закривали вузловими швами. Поверхню рани обробляли антисептичним аерозолем.

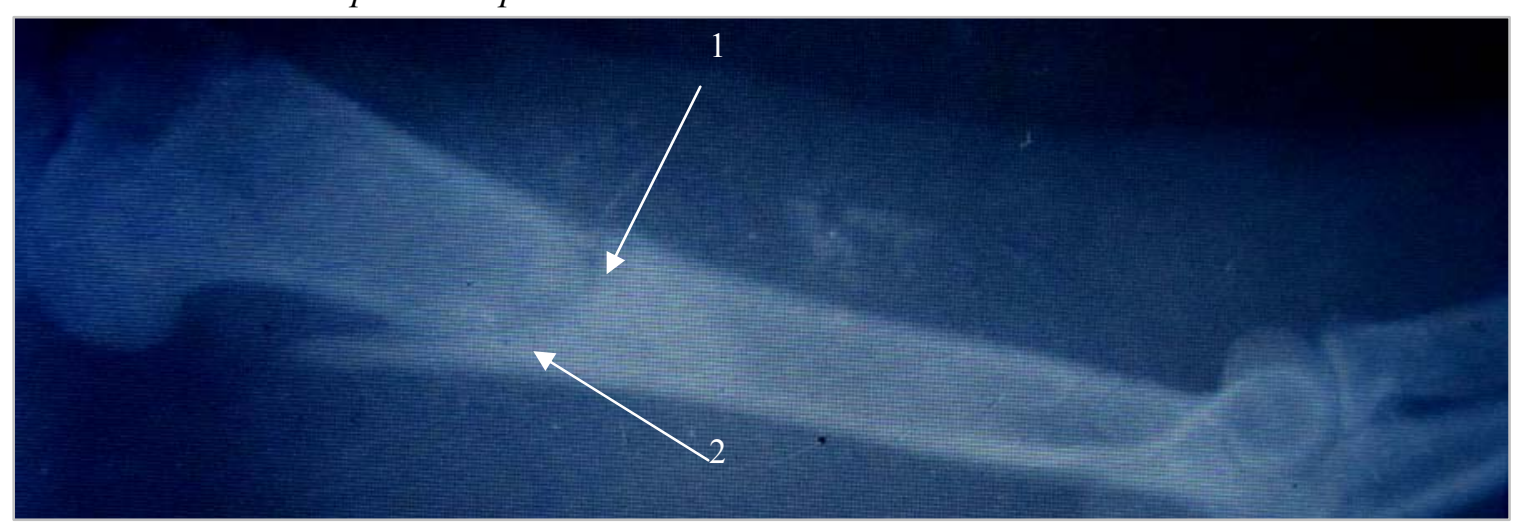

Рис. 3. Ренттенограма плечової кістки кота з патологічним переломом у ділянці деструкції: 1 - секвестральна коробка; 2 - лінія перелому 
Рентгенологічні дослідження показали, що через десять діб після кісткової пластики остеотропні імплантанти серії «Біомін» досить щільно заповнювали дефект і мали чіткі контури (рис. 4).
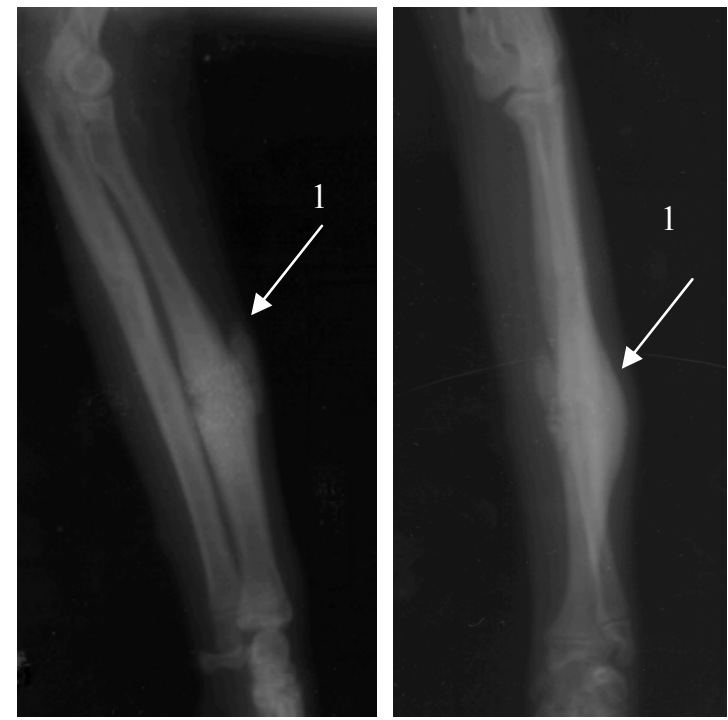

Рис. 4. Ренттенограма кісток передпліччя кота на десяту добу після вживляння транульованого імплантанта Біомін-

гТлС. Пряма та бокова проекції:

1 - переостоз із кістковою мозоллю

Через 20 діб після вживляння в кісткову порожнину імплантантів реєстрували виражені ознаки позитивної динаміки із заповненням осередку деструкції звапненим вмістом і його злиттям із навколишньою кістковою тканиною, периостозом та склерозом окістя, звапненням м'яких тканин у ділянці патологічного процесу (рис. 5). Імплантанти втрачали чіткість і зливалися з оточуючою кістковою тканиною; за своєю щільністю вони наближалися до спонгіозної кістки. Спостерігалася виражена ендоостальна реакція, періостальні нашарування з ознаками звапнення.

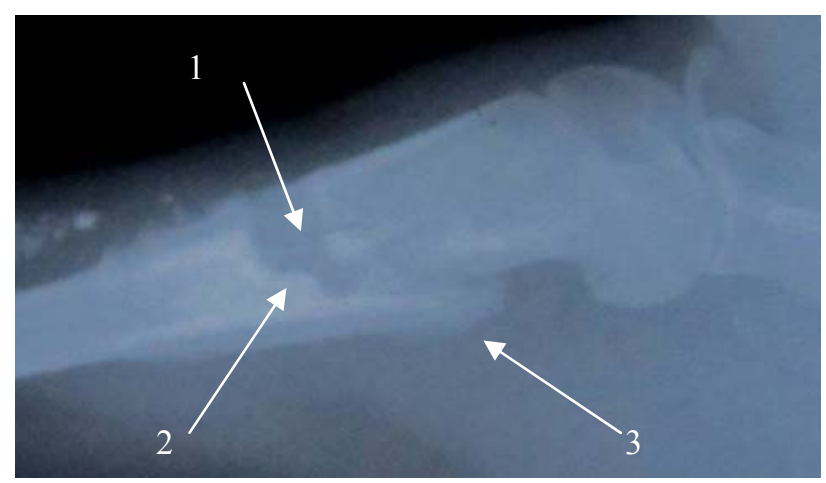

Рис. 5. Ренттенограма плечової кістки кота на двадцяту добу після вживляння транульованого імплантанта Біомін-гТлС:

1 - секвестральна коробка; 2 -лінія перелому; 3 - реакиія окістя
Через 30 діб відбувалося повне заповнення дефектів губчатою кістковою тканиною, контури дефекту й імплантанта були нечіткими (рис. 6).

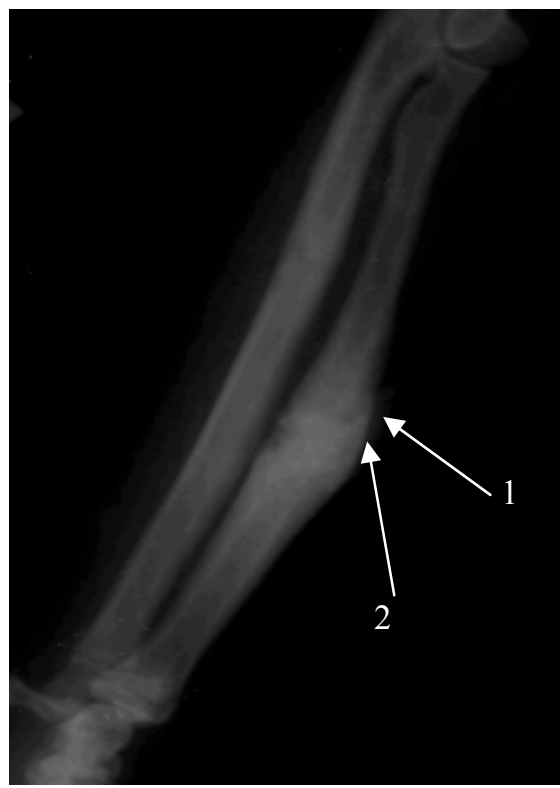

Рис. 6. Ренттенограма кісток передпліччя кота на тридцяту добу після вживляння транульованого імплантанта Біомін-

гТлС: 1 - переостоз; 2 - секвестральна коробка, заповнена кістковою тканиною

Продовження позитивної динаміки спостерігали на рентгенограмах через чотири місяці після початку лікування. Дефект заповнювався кістковою тканиною, реєстрували повне відновлення кортикального шару кістки (рис. 7).

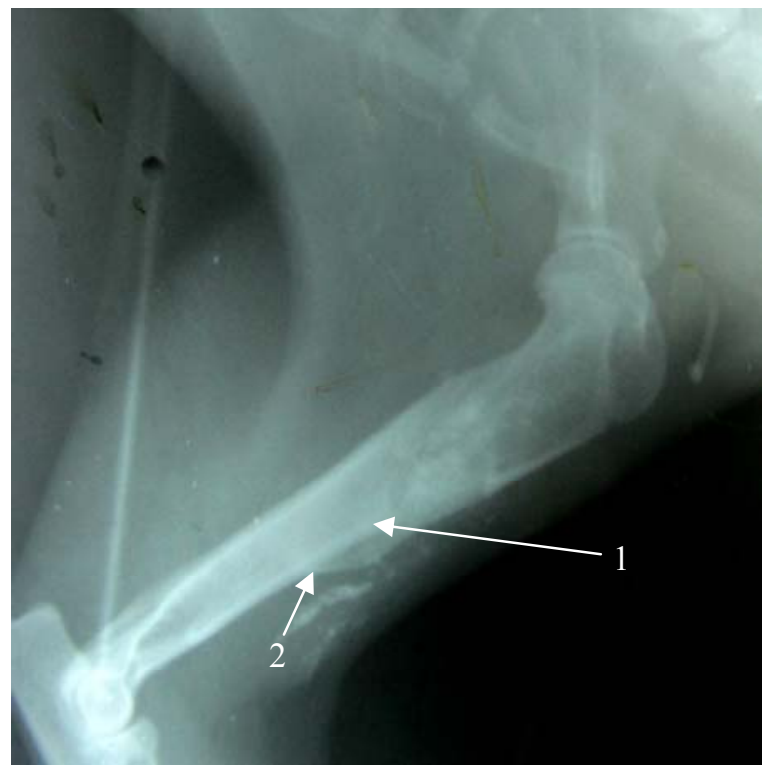

Рис. 7. Ренттенограма плечової кістки через 4 місяці після вживляння

транульованого імплантанта Біомін-

гТл С: 1 - кісткова мозоль; 2 - оссифікація м'яких тканин 


\section{СТОРІНКА МОЛОДОГО ВЧЕНОГО}

На серії рентгенограм гілки нижньої щелепи в ділянці коренів V-VI зубів нами також зареєстрована виражена позитивна динаміка лікування експериментально відтвореного остеомієліту імплантантом серії «Біомін».

Через 20 діб після введення імплантанта в осередок патологічного процесу відмічали заповнення порожнини кістки звапненим вмістом, межі дефекту стали розмитими й зливалися 3 навколишніми тканинами (рис. 8).

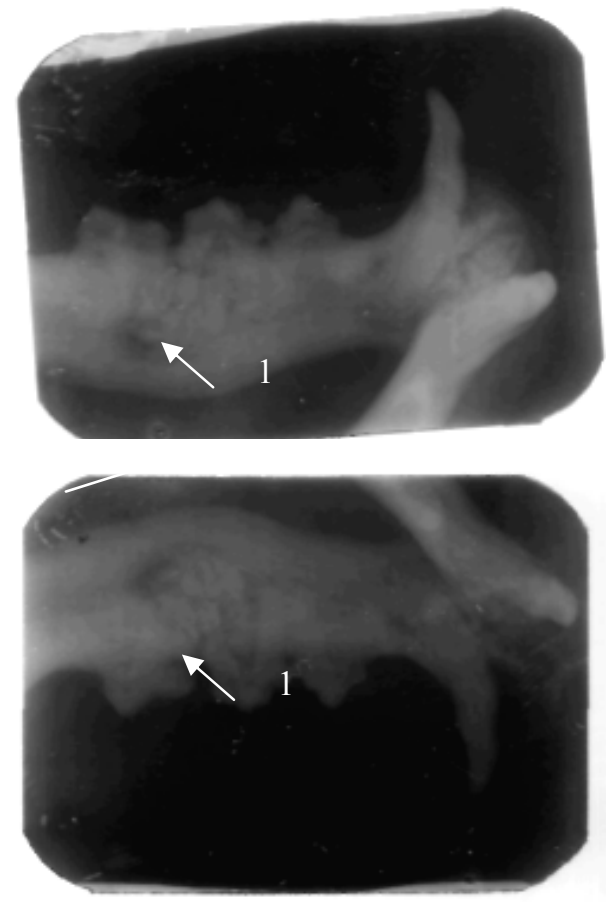

Рис. 8. Ренттенограми нижньої щелепи кота (права гілка) через 20 днів після вживляння гранульованого імплантанта

Біомін-гТлС: 1 - полоска просвітлення

Через два місяці після проведеного лікування дефект заповнювався новоутвореною кістковою тканиною (рис. 9). Через п’ять місяців реєстрували повне відновлення кісток нижньої щелепи (рис. 10).

\section{БІБЛІОГРАФІЯ}

1. Арсеньев И. Г. Экспериментально-морфологическое обоснование клинического применения деградируемых биоимплантантов в комплексном лечении переломов и ложных суставов длинных трубчатых костей : дис. ... канд. мед. наук : спец. 14.00.22 «Травматология и ортопедия» / И. Г. Арсеньев. - М., 2007. - 200 с.

2. Березенко М. Н. Стимуляция репаративного остегогенеза при лечении больных с переломами длинных трубчатих костей и шейки бедренной кости (клиническое ииследование) : дис. ... канд. мед. наук : спец. 14.00.22 «Травматология и ортопедия» / М. Н. Березенко. - М., 2005. - 106 с. 3. Зедгенидзе Г. А. Клиническая рентгенорадиология / Г. А. Зедгенидзе. - М. : Медицина, 1984.- 464 с.

4. Панин М. Г. Десятилетний опыт реконструк-

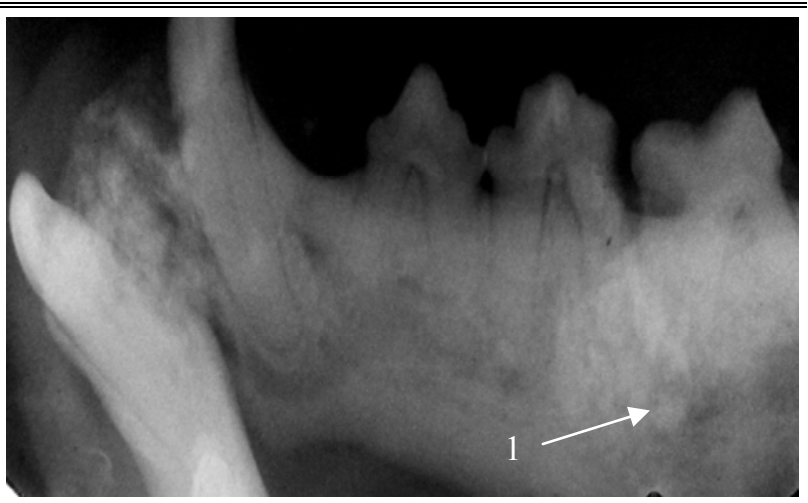

Рис. 9. Рентгенограма нижньої целепи кота (права гілка) через два місяці після вживляння гранульованого імплантанта

Біомін-гТлС: 1 - изікковите заповнення порожнини імплантантом

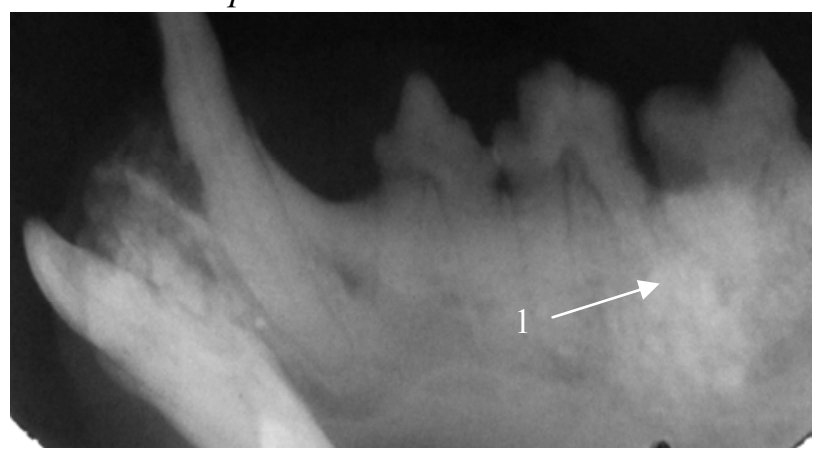

Рис. 10. Рентиенограма нижньої щелепи кота (права гілка) через п'ять місяців після вживляння імплантанта Біомін-

гТлС: 1 - иілковите заповнення порожнини імплантантом

Висновок. Згідно 3 даними рентгенологічних досліджень, застосування остеотропних імплантантів серії «Біомін» для пластики кісткових дефектів забезпечує активізацію репаративного остеогенезу та відтворення анатомічної форми i структури кістки. Тому застосування даного матеріалу є доцільним компонентом комплексного лікування остеомієліту котів.

тивной хирургии нижней челюсти / М. Г. Панин, Е. П. Лаптев, В. С. Агапов // Конструктивные и реконструктивные операции в челюстнолицевой области. - 1985. - С. 46-48.

5. Bovne P. Evalution of a ceramic hydroxyapatite in femoral defects / P. Bovne, B. Fremming, R. Walsh et al. // Dent. Res. - 1978. - V. 57. - P. 108-111.

6. Chuong $R$. A retrospective analysis of 327 mandibular fractures / R. Chuong, R. Donoff, W. Guralnick // J. Oral Maxillofac. Surg. - 1983. V. 41. - P. 305-312.

7. Gregg A. DuPont. Atlas of dental radyography in dogs and cats: a practical guide to techniques and interpretation / Gregg A. DuPont, Linda J. DeBowes. - Saunders, 2009. - 288 p. 